\title{
Analyzing Social Meaning: \\ How Words Matter in Social Contexts (Based on German Communicative Practice)
}

\author{
Sergei T. Nefedova and Valeria E. Chernyavskaya*b \\ ${ }^{a}$ Saint Petersburg State University \\ St. Petersburg, Russian Federation \\ ${ }^{b}$ Peter the Great St. Petersburg Polytechnic University \\ St. Petersburg, Russian Federation
}

Received 12.08.2021, received in revised form 22.08.2021, accepted 14.09.2021

\begin{abstract}
The paper discusses the notion of social meaning that has become a central one in sociolinguistics, linguistic anthropology, metapragmatics. The study was informed by these research directions and the main outcomes. The term social meaning pinpoints what linguistic forms convey about the social identity of the users, about their personality, social features and ideologically, value-based orientations. We presume that this is a category of meaning that a linguistic unit (an utterance) obtains as a result of its usage in a certain context. Social meanings are fixed by social practice. It acts as an index to the context in which the linguistic unit is expected to be used and relevant. Indexical relations are open for re-evaluations that are mediated by speakers ideological views. The study is based on German socio-cultural practice and reveals how indexical relations arise between a linguistic unit and the socio-cultural environment, the social occasion of its usage. The analysis is conducted as corpus-assisted discourse analysis, based on the «Digital dictionary of the German language» / «Das Digitale Wörterbuch der deutschen Sprache».
\end{abstract}

Keywords: sociolinguistics, social meaning, indexicality, corpus-based discourse analysis.

Research area: linguisctics.

Citation: Nefedov, S.T., Chernyavskaya, V.E. (2021). Analyzing social meaning: How words matter in social contexts (based on German communicative practice). J. Sib. Fed. Univ. Humanit. soc. sci., 14(10), 1556-1566. DOI: 10.17516/1997-1370-0839

(C) Siberian Federal University. All rights reserved

* Corresponding author E-mail address: tcherniavskaia@rambler.ru 
Социальное значение: что значат слова

в социальных контекстах

(на материале немецкой

коммуникативной практики)

\author{
C.Т. Нефедов ${ }^{\text {a }}$ В.Е. Чернявская ${ }^{6}$ \\ ${ }^{a}$ Санкт-Петербургский государственный университет \\ Российская Федеращия, Санкт-Петербург \\ ${ }^{6}$ Санкт-Петербургский политехнический университет Петра Великого \\ Российская Федераиия, Санкт-Петербург
}

\begin{abstract}
Аннотация. В статье обсуждается понятие социального значения и социальной индексальности языкового знака, ставшее центральным в социолингвистике третьей волны, лингвистической антропологии, метапрагматике. Теоретико-методологические основания проведенного исследования заданы этими направлениями. Термин «социальное значение» отражает, как изучение языковой вариативности становится инструментом, активно используемым человеком/социальной группой для выражения и конструирования социального мира и идентичности. Мы исходим из того, что это особый тип значения, которое языковая единица (высказывание) получает в результате своего использования в определенном контексте. Социальные значения фиксируются социальной практикой. Социальное значение индексально, указывает на контекст, в котором предполагается использовать лингвистическую единицу. Индексальные отношения динамичны, открыты для переоценки, опосредованной идеологическими взглядами говорящего. Исследование проведено на материале немецкой социокультурной практики и показывает, как возникают индексальные отношения между языковой единицей и социокультурной средой, социальным поводом ее использования. Анализ проведен как корпусно-ориентированный дискурсивный анализ на основе «Цифрового словаря немецкого языка» / «Das Digitale Wörterbuch der deutschen Sprache».
\end{abstract}

Ключевые слова: социолингвистика, социальное значение, индексальность, корпусноориентированный дискурсивный анализ.

Научная специальность: 10.02.00 - языкознание.

\section{Introduction}

The point of departure for the suggested analysis is that «language use is a key element of social practice, but it is practices that generate the meanings that we take to define our social lives» (Coupland, Jaworski, 2009: 9). The paper aims at 'language-in-society', at social nature of discourse, that reflects all meaningful aspects of socio-cultural, political, ideological environment. The notion of social meaning has become a central one in the undertaken analysis. By a social meaning we mean a category of meaning that a linguistic unit (or an utterance) obtains as a result of its usage in a certain context. Social meanings are fixed by social practice. It is defined as an index, marker of the context in which the linguistic unit is expected to be used and relevant. The term social meaning pinpoints what linguistic forms convey about the social identity of the users, about their personality, social features and ideologically, value-based orientations. What is of importance is the ideological load that the linguistic unit gains due to its previous usage contexts and existing evaluative angles. A social meaning / social index of a word and «its» context generate 
stable frames of perception and interpretation. Thus indexicality deals with meaning that we do not say or write, but express by indexing at the contexts where they fit.

We presume that the word is the most sensitive index of any social change, as Voloshinov put it. The word is social by nature. Its meaning construction comes to life in the transition from one context to another context, from one generation to another generation. At the same time, the word cannot completely free itself from the power of those specific contexts into which it entered. In this sense, the word comes from another context, fueled with other people's intentions. That is why the orientation of a word among words, a different feeling of someone else's word are, perhaps, the most essential problems of the sociology of the word (Voloshinov, 2000 [1926]: 77-78).

Many linguistic forms become socially meaningful. Indexical relations are open for being reevaluated and such reevaluations are mediated by speakers ideological-based views. Therefore language users may vary in their interpretation of the social significance of linguistic forms. Over time, indexical links go through further evaluation in the social practice, adopting another specific features ideologically related to the original association.

Significant cases in this framework come from the German language and communicative practice that convey socially meaningful differences in using language before and after reunification Germany in 1990. German was spoken on both sides of the wall. But there were linguistic peculiarities. The language of the former GDR had its own markedness in terms of social collective identity of the users. In the present investigation we take the social networking of the German word Kollektiv and social effects of its usage in the current sociocultural practice compared with the past communicative practice the German Democratic Republic before 1990.

\section{Theoretical Background of the Study}

The concepts of culture and context are regarded as crucial in the present study. The definition of culture rests on a methodological alternative suggested for the meaning of this notion. There are research directions which offer Humboldt's approach and related linguocultural conceptions which consider language as an ethnic (national) language and culture as an ethnic (national) phenomenon. Another research direction, namely a discourse sensitive approach to the notion of culture is to be discussed. According to this explanatory approach culture is defined as a discourse practice, as a process of social construction. In this process the existent systems of knowledge, meanings and ideas contribute to social interaction only when they set transpersonal markers and construct identities, see e. g. (Gasparyan, Cherniavskaia, 2014; Tcherniavskaia 2014). The present investigation draws on the discourse sensitive approach. We rely on the four crucial aspects:

culture reflects forms of human's material and spiritual life and ways of their regulating; it means a set of rules which prescribe and at the same time limit ideas about what is considered as norm and as accepted behaviour in a society; culture manifests itself in a social context; culture takes some shape relying on semiotic tools for its expression.

Ideas about cultural specificity of human's communicative-speech activity are closely related to the notions of context and contextualization. As Halliday, Hasan put it, «there was a theory of context before there was a theory of text» (Halliday, Hasan, 1985: 5). A pioneering approach to language and context was developed by British anthropologist B. Malinowski, who studied the culture and language of indigenous population of Australia and New Guinea in the 1920s. He initiated the debate about context embeddedness of a linguistic unit: to understand a meaning of a word in a language which does not have a writing system one should learn about its function in the context which this word is pronounced in. It is important to investigate usage contexts of the word to be able to understand its meanings. Later Malinowski developed his own approach to language in general: cf. «the real understanding of words is always ultimately derived from active experience of those aspects of reality to which the words belong» (Malinowski, 1935: 58). Actually, Malinowski introduced the discourse 
sensitive approach in its current interpretation, in a way it is developed in sociolinguistics, linguistic anthropology, culturological linguistics, see e. g. (Blommaert, 2005; Bucholtz, Hall, 2008; Bucholtz, Hall, 2011; Collins, 2011; Eckert, 2018).

A particular interest to the concepts of social indexicality and social meaning as an analytical tool has led to significant results in sociolinguistic studies of American and Western European scientific schools, in linguistic anthropology and metapragmatics. Contemporary schools of thought are represented by Michael Silverstein, Penelope Eckert, and Asif Agha in the USA, by Mary Bucholtz, Kira Hall, Nikolas Coupland in the UK, by Jan Blommaert in the Netherlands, and by Jürgen Spitzmüller, Barbara Soukup in Austria. There has emerged a new research trend oriented towards studying implicit latent meanings in contrast with other analytical approaches to investigating a language in a society.

Thus, pragmatically-oriented linguistics, stylistics, text linguistic have formed a functional approach to communication. They describe communication as a result of exercised choice of a number of options, as deliberate planning of communicative actions. From a strategic perspective, communication is analysed as linguistic choices made following a certain strategy. Therefore linguistic choices are defined as resources or tools for achieving communicators' strategic goals. In this respect theoretical background was established by pragmatically-led linguistics and its branches such as functional stylistics, pragmatic stylistics, text stylistics and text linguistics. There developed diverse conceptions of argumentation, neorhetoric, persuasive communication, direct and indirect communication, explanatory methods of linguistic persuasion and manipulation. In this perspective the explanatory approach is based on a pragmatic, related meaning of a linguistic unit, namely, a connotation which is firmly associated with its core meaning in the communicators' minds. According to this approach nomination (the choice of a word to name some referent) reflects a subjective, ideologically-charged meaning, whereas alternative nomination (re- nomination, labelling) can be regarded as a persuasive tool. Choosing alternative nomination enables to form preferred evaluation and predicted addressee's response. About debate and outcomes see in (Kulikova, 2011; Nefedov, 2019; Nefedov, 2021; Nefedov, Chernyavskaya, 2020; Chernyavskaya, 2020).

'Function' and 'functional perspective' is a broad concept. It has become central in sociolinguistics in different dimensions. One of it is social meaning, as introduced above. Ideas about social meaning as an index are not related only to pragmatic meaning as a connotation. Social meaning describes not only linguistic variations in language use, but also provides explanations in relation to the significance of a linguistic resource for speakers/listeners. Speakers are seen as social agents, who are able functionally to achieve certain senses when using linguistic resources or, in other words, making choice between them.

The conception of social indexicality is seen as a different research angle which has also resulted from a pragmatic shift in linguistics. This new perspective has put a major emphasis on context dependence of a meaning and reflection on language usage. Theoretical framework of linguistic indexicality was established by R. Jakobson who included a metalingual function and an active user/observer in the communication model (Jaconson, 1980 [1957]). This idea was then reinterpreted in American anthropology by M. Silverstein (Silverstein, 1979; 2003). Studying language pragmatic function has led to understanding that numerous meanings of a linguistic form arise from indexical relationships between a linguistic sign and its usage context. Silverstein underlined that conscious and critical attitude of the user to linguistic resources became a central factor of language development and functioning. He also claimed that meanings of linguistic signs were interrelated with situational context of their usage as well as with culturally specific conceptions and norms. Thus, when a linguistic sign is indexically connected with its context, the frame of perception appears. In this case reflection of a person who realizes how and why he/she uses some linguistic means generates stable frames of perception 
and interpretation. To quote Blommaert, «referential or denotational, 'pure' meaning is only one part of the effects of language use. Apart from referential meaning, acts of communication produce indexical meaning: social meaning, interpretive leads between what is said and the social occasion in which it is being produced (...) Every utterance also tells us something about the utterance itself. Is it serious or banter? Is this an anecdote, a joke, an order, a request? Is the speaker sure/sincere/confident of what s/he says? What kind of relationship between the speaker and the hearer is articulated in this utterance - is this a friendly or a hostile utterance? And every utterance tells us something about the social context in which it is being produced... Are things such as social class, gender, ethnicity, or professional status played out in the utterance? Are social roles reinforced or put up for negotiation? Are social rules being followed or broken? And so on. Indexical meaning is what anchors language usage firmly into social and cultural patterns»» (Blommaert, 2005: 11-12).

The following point should be particularly stressed. Focus on indexicality and the introduced notion of social index/ social meaning neither contrast nor offer an alternative to other types of signs as it was described in Ch. Peirce's semiotic sign model - icons, symbols and indices.

What is important in the light of the undertaken analysis is that the linguistic form used by an individual in a certain situation (in discourse) is indexically connected with the person's social characteristics and elements of the context. In this respect it is notable that in existing English research term languaging has been preferably used as an alternative to term language to describe dynamic usage of language resources. The term of languaging has been used to mean practice of using a language focussing on the action of an individual using a language, his/her ability to choose a linguistic means appropriate to a particular situation.

It has become important, that indexicality appears to operate in the intertextual environment within an archive, «a historical 'system of the formation and transformation of statements' in Foucault's terms, and they should be seen as the empirical side of such a system. The system operates at the lowest level by imposing 'conventional', normative indexical meanings to utterances and communicative events, a task usually fulfilled by centring institutions such as the state, schools, role models, peer groups, cultural icons... The main advantage of the concept of an archive, however, is that it reminds us of the limits within which discourse operates, of the constraints on choice and creativity in discourse» (Blommaert, 2005: 103). This implies that meaning is not only contextbased but also context-determined.

\section{Methodology}

We analyze the social meaning of the word Kollektiv and its usage in the socio-cultural practice. These will illustrate how social effects marking the use of a linguistic unit in a certain social environment arise and become indexical. The analysis is conducted as corpusassisted discourse analysis, based on the «Digital dictionary of the German language» / «Das Digitale Wörterbuch der deutschen Sprache». It is a lexical-semantic system of words and their text occurrences ( 27 billion tokens) global for German sociocultural space. Corpus-based tools allow to observe dynamic processes of contextualization of a certain linguistic unit and to describe a social meaning which it acquires resulting from interaction of the conventional meaning of a lexeme with a context (Chernyavskaya, 2019). Initially, dictionary data about the lexeme of Kollektiv given in «Digital dictionary of the German language» were collected. This stage revealed how a typical structure of the lexical meaning of the given lexeme and meaning of the notion it names are reflected in the language usage. To conduct this part of the research the search-analytical tool of OpenThesaurus integrated in the «Digital dictionary of the German language» was used. Then we studied the dynamic of the word usage in the corpus and marked the 'return' of lexeme Kollektiv in active usage in 2020 in coronavirus pandemic. The next step included use of special corpus of electronic texts on coronavirus pandemic (das Corona-Korpus). It contains over 71,000 texts. The corpus includes three major text corpora: weekly online 
German newspapers and magazines, medical online newspapers and news reports, personal sites and blogs of well-known sociologists, politicians, people of science and art.

The procedure of the corpora analysis consisted of two stages. At the first stage the search engine of Dialing Concordancer (DCC) (integrated in "Digital dictionary of the German language») was used to set a maximum possible format of extracted verbal component of the lexeme under discussion, namely, a text set of a three-sentence size measured from fullstop to full-stop irrespective of its structural integrity. At the second stage 250 contexts of key word Kollektiv occurrences were extracted by the search tools of the engine. This meant that the word under consideration was part of the coronavirus pandemic corpus. Each text set was analysed using pragma-semantic methods.

\section{Data and Interpretation}

To observe social effects of language use we have addressed the word Kollektiv in the German language. The core of concept Kollektiv (its archiseme) contains such semantic items as numerous and antroponymic, i. e. uniting of separate individuals in a group. Lexeme Kollektiv is used to define a social group of people as well as a social model of people's behaviour within this group and the relationships that arise between the people.

Kollektiv belongs to a set of words and notions which have become most socially sensitive and reflecting evaluative concepts. This attitude to this linguistic unit was shaped after the unification of the Federal Republic of Germany and the German Democratic Republic into a single state in 1990. Researchers claim that word Kollektiv refers to the group of words which are interpreted as a sign of social practice characteristic of East Germany during the socialist period (Keßler, 1997; Keßler, 2004; Reiher, 2000). It serves as an index referring to the period of the German Democratic Republic. Its usage activates links with Germany of the socialist epoch and practice of the past. In socialist Germany Kollektiv was one of the key words which was spread and fixed in people's minds and was emotionally appealing and was perceived uncritically. Use of noun Kollektiv and collocations with adjective kollektiv was stereotypized and related to social identification. This can be clearly traced in such collocations as to hold strong positions in a collective; to be a respectable member of a collective; to have a positive impact on a collective. In this light assumptions about social and group identity, about what means to be a 'member of a collective' rely on positive connotations such as to be helpful, to give solidarity support, to be generous. Thus, the notion of collective enters the list of interrelated concepts like equality, help and support, a feeling of security, solidarity (Keßler, 2004).

Notably, after reunification of Germany in one state in 1990, using a word Kollektiv in the meaning of «collectively; affecting all parties involved» has become pejoratively framed. It causes a pejorative impression and negative associations. These include forced uniting of people in a team, controlled by the government; a vigilant watch; government practice of setting general boundaries for an individual; invasion of privacy, cf. in German: Einengung des persönlichen Handlungsspielraums, Unselbständigkeit, Zwang sich anpassen zu müssen, Unterdrückung. As social surveys showed and discourse research indicated, such concepts as autonomy, identity, self-reliance are focused as semantically opposed to the notions of a collective, solidarity. So, word Kollektiv has become one of the controversial concepts.

In explaining the changed communicative practice, Keßler presented the results of the social survey in an authoritative German newspaper «Zeit» dated 29.12.1999. It had been conducted in federated states of pre-unified Germany since 1976 and federated states being part of the German Democratic Republic before the unification process since 1990. The central aim of the survey was to reveal emotions which the words as well as concepts and values that they express evoke in German people. Among the words under consideration were the following: labour, communism, feminism, a collective and others. The 1999 survey results show that $55 \%$ of the respondents (federated states of pre-unified Germany) reacted negatively to word Kollektiv referring to the word as «unpleasant». Sixty-six per cent of the 
respondents (Eastern federated states) referred to this word as «pleasant» whereas $24 \%$ of the respondents associated it with something unpleasant (Keßler, 2004).

Preferred synonym to define a group or a team of people in modern German is an English borrowing team. As Reiher put it, «the «collective» has said goodbye to the «team» in German public discourse (Reiher, 2000). Word team seems to have completely replaced lexeme Kollektiv when referring to a social community. The latter is occasionally used to name sports teams, small professional groups, musical bands. It appeared to be clearly ideologically marked as it provides a reference to social practice of the German society in the past and it is evaluated as unwanted, unattractive, emotionally unpleasant. A prevailing attitude to the notion expressed by lexeme Kollektiv is primarily as follows: forced uniting of people, controlled by the government.

To explore the real life of this word in the current practice and the contexts of meaning we used the «Digital dictionary of the German language» / «Das Digitale Wörterbuch der deutschen Sprache (DWDS)». Acording to the «Digital dictionary», after 1990 there was a dramatic fall in its usage rate, relative frequency of the lexeme usage fell dramatically since 1990 (Digital dictionary of the German language https://www.dwds.de/r/ plot $/$ ?view $=1 \&$ corpus=zeitungen $\&$ norm $=$ date $\% 2$ Bclass \& smooth $=$ spline \& genres $=0 \&$ grand $=1 \&$ slice $=1 \&$ prune $=0 \&$ window $=3 \&$ wbase $=0 \& \log$ avg $=0 \& \operatorname{logscale}=0 \& \mathrm{x}-$ range $=1946 \% 3 \mathrm{~A} 2021 \& q 1=$ Kollektiv; access date 01.08.2021). Currently, however, there is a gradual rise in the word usage in the corpus. Year 2000 showed 3.74 occurrences of the lexeme under consideration in relation to $1 \mathrm{mln}$ word occurrences. This number increased to 4.01 in 2010. It is notable that year 2020 considered as the year when the pandemic began marked the return of lexeme Kollektiv in active usage. Moreover, in 2021 there has been twice as many occurrences of this word compared to 2000: 7.07 word occurrences (Digital dictionary of the German language https://www.dwds. $\mathrm{de} / \mathrm{r} / \mathrm{plot} /$ ?view $=1 \&$ corpus=zeitungen \&norm=date $\% 2$ Bclass \& smooth $=$ spline \&genres
$=0 \&$ grand $=1 \&$ slice $=1 \&$ prune $=0 \&$ win dow $=3 \&$ wbase $=0 \& \log a v g=0 \& \operatorname{logscale}=0 \& \mathrm{x}-$ range $=1946 \% 3 \mathrm{~A} 2021 \& q 1=$ Kollektiv; access date 01.08.2021).

Indexical connection of word Kollektiv with a certain social practice of its usage, namely forced uniting of people, has become increasingly apparent in a new social practice in the coronavirus pandemic. The pandemic opened up a wide range of opportunities for the government to invade people's privacy. What can be observed now is the practice of infringing people's personal liberties as well as return of word Kollektiv in communication. Lexeme das Kollektiv has begun to be used again to reflect a changing social practice and life in the German society. Neoliberal, hedonistic values rooted in the minds of the majority of Germans faced opposition to harsh objective reality reminding the people of collective responsibility and need for government control. As known, people's opinions divided on the matter of coronavirus restrictions. Some people completely rejected collective coronavirus restrictions and organized protests against attack on the rights and liberties of individuals, whereas others called for prudence to collectively overcome the global threat.

The declared analysis procedure established, firstly, that the notion, that lexeme Kollektiv refers (denotes) to, has divers content. And, secondly, it is used in the communication acts in a different semantic status. In most of the extracted contexts the lexeme is used in a denotative meaning without additional evaluative meanings. One hundred and sixty contexts in the «Corona-Corpus» reveal the use of das Kollektiv to refer to groups of patients infected by coronavirus as well as the use in a neutral meaning to refer to sports teams and musical bands.

In 87 contexts in the "Corona-Corpus» this lexical form is used in the semantic oppositions «individual - society», «liberalism/ individualism - collectivism». When using this form, social actors mark a critical discussion or ideological dispute about the current pandemic situation. At the same time, the value-based nature of the concept of Kollektiv transfers it to the ideological orientation of the social actors 
and expresses their evaluative attitude to what is communicated in the course of communication. In terms of logical semantics, these types of linguistic implementation of the Kollektiv lexeme correspond to two different semantic statuses: description (nomination) and assessment (qualification).

Fifty-one contexts indicate the use of lexeme das Kollektiv to mean «forced uniting of people during self-isolation period». In these cases the lexeme under analysis occurs in the right and left environment of positivelycharged linguistic units, such as protection, right decision. In the corpus such examples are typically met in the printed press and personal web-pages of left-wing parties calling for people to sacrifice their neoliberal values for the sake of prudence. The following examples can serve as an illustration ${ }^{1}$.

(1) Es sind ja gerade die weniger drakonischen Maßnahmen der deutschen Politik, die uns hierzulande eine Freizügigkeit mitten im Ausnahmezustand ermöglichen.Voraussetzung für diese gefühlte Leichtigkeit des Seins war in den vergangenen Wochen der Konsens, dass jeder Einzelne in dieser Krise nicht nur eigenverantwortlich handelt, sondern sich auch als Teil eines Kollektivs der Gleichgesinnten begreift: Ich trage die Gesichtsmaske nicht nur zu meinem Schutz und halte Abstand, ich tue das auch, um die anderen zu schützen. (Andreas Borcholte. Debatte um CoronaLockerungen: Neue Normalität? Leider ganz die alte - DER SPIEGEL - Kultur https://www. spiegel.de, 02.05.2020).

It is precisely less draconian measures of German politics that enable us in this country to move freely in the middle of a state of emergency. The prerequisite for this felt lightness of our life was in the past few weeks the consensus that each individual in this crisis would not only act independently, but also would see himself as part of a collective of like-minded people: I don't just wear the face mask for my protection and keep my distance, I also do that to protect the others. (Andreas Borcholte. Debate about corona easing: new normality? DER SPIEGEL - Kultur https://www.spiegel. de, 02.05.2020).

\footnotetext{
translation made by the authors
}

(2) In der Krise richten sich alle Erwartungen auf das Kollektiv, dabei lassen sich Notlagen nur bewältigen, wenn Individuen die richtigen Entscheidungen treffen. In Bergamo, dem europäischen Epizentrum der Seuche, gaben Ärzte und Ärztinnen, Krankenschwestern und Pfleger trotz Infektionsrisiko und Erschöpfung nicht auf (Eric Gujer. Coronavirus: Nach der Corona-Krise braucht es weniger Staat. Neue Zürcher Zeitung, https://www.nzz. ch, 17.04.2020).

In a crisis, all expectations are directed towards the collective, but emergencies can only be coped with when individuals make the right decisions. In Bergamo, the European epicenter of the disease, doctors and nurses did not give up despite the risk of infection and exhaustion (Eric Gujer. Coronavirus: After the corona crisis, less government is needed. Neue Zürcher Zeitung, https://www.nzz.ch, 17.04.2020).

Thirty-six contexts with the evaluative use of the lexeme Kollektiv reveal open confrontation and disagreement of social actors with the official policy of the authorities. The lexeme Kollektiv is used to name a historically discredited model of social life. This lexeme in a pejorative aspect is surrounded by linguistic units with semantics of unwanted, forced uniting of people into a community: threat, control, restriction. The linguistic form of Kollektiv focuses the opposition and, moreover, the split between the forced uniting of people, made by the state, and individual rights and freedoms. For example:

(3) Mit konkretem Leid können wir umgehen. Das abstrakte aber stellt unsere Menschlichkeit ganz anders auf die Probe. Wenn man das Unglück aus der Nähe erlebt hat, dann wusste man, um wen und um was es geht. In den jetzigen Zeiten nehmen wir Anteil am Leben von Menschen, die nur Zahlen sind. Wo sollen wir da hin mit unserem Mitleid und unserer Menschenfreundlichkeit? In der großen Krise wird alles zum Kollektiv. Wir sind Quarantänepersonal und Statisten von Vorgängen, die der Gesundheit aller dienen sollen ... (Paul Jandl. In der Corona-Krise wird jeder zu einer Dunkelziffer. Neue Zürcher Zeitung. 18.05.2020. https://www.nzz.ch/ feuilleton/in-der-corona-krise-wird-jeder-zu- 
einer-dunkelziffer-ld.1556786?reduced=true; access date 28.03.2021).

We are able to relieve a particular pain. However, abstract pain checks for our humanity in a different way. When you personally suffer some tragedy, you know exactly who or what it is about. Currently we deal with people who are mere numbers. Where should we address our sympathy and love for our neighbour? During the global crises everything becomes a collective. All of us are quarantined and are the crowd of extras at the event who have to sacrifice for the sake of people's health. (Paul Jandl. Neue Zürcher Zeitung. 18.05.2020. https://www.nzz.ch/ feuilleton/in-der-corona-krise-wird-jeder-zueiner-dunkelziffer-ld.1556786? reduced =true; access date 28.03.2021).

(4) An der Verwendung des Solidaritätsbegriffs lässt sich also detailliert nachvollziehen, wie Sicherheit diskursiv, aber auch politisch funktioniert: als Generator imaginierter bedrohter Kollektive, als Technik des Regierens und als Rhetorik der Drohung. Dies ist angesichts der begrifflichen Prägung der «Solidarität» bemerkenswert, tauchte der Begriff in tradierten Kontexten vor allem doch als Inklusions- und Kampfbegriff auf. ... Sie setzt eine Vergangenheit voraus und muss in der Gegenwart zu einem greifbaren Faktor zusammenzufassen sein: der Übereinkunft, dem deutlich ausgesprochenen Wunsch, das gemeinsame Leben fortzusetzen. Zum anderen evoziert der Appell an Solidarität auch die Vorstellung eines Kollektivs, in dessen Namen Verzicht geübt werden soll. Praktiken des Verzichts gelten dann zugleich als Beweise der Zugehörigkeit. (Thorsten Bonacker. Solidarität als Sicherheitsformel. Soziopolis, 08.04.2020. https://www.soziopolis.de/solidaritaet-alssicherheitsformel.html).

The notion of solidarity may help to illustrate how the meaning of security functions at the discourse and political levels, namely, as the creator of virtual collectives subject to danger, as a control tactics and as threat rhetoric. This seems to be much more remarkable due to stable character of the meaning of solidarity concept as this notion occurred mainly in the contexts of cooperation and struggle. This no- tion refers to the past and should be conceived as a real factor in the present: as agreement, as a strong will to continue collective life. However, call for solidarity evokes ideas of the collective for the sake of which restrictions should be imposed. In this case placing restrictions refers to the collective belonging. (Thorsten Bonacker. Solidarität als Sicherheitsformel. Soziopolis, 08.04.2020. https://www.soziopolis. de/solidaritaet-als-sicherheitsformel.html).

(5) Von höchster Brisanz ist die faktische Verschiebung der gesellschaftlichen Zentralperspektive, des - sozusagen - gesellschaftsphilosophischen Primats: Für gewöhnlich stellt dies - der feste Fokus auf den Einzelnen - ein Fundament liberaler, freiheitlicher, humaner, demokratischer Gesellschaften dar, einen höchst sensiblen Indikator für gesellschaftliche Verhältnisse. Er ist, hat sich historisch gezeigt, ein verlässliches Gegengift gegen alle autoritären und totalitären Doktrinen, die das "Allgemeine», das Kollektiv - das «Volk», die «Volksgemeinschaft» etc. - als vorrangigen Gesichtspunkt installieren und den Einzelnen nichten, das widerliche Verfahren ist bekannt. (Jörg Bong. Corona-Exit-Debatte: Imp$f t$ Euch gegen das Virus der Barbarei! DER SPIEGEL - Kultur. 03.04.2020. https://www. spiegel.de/kultur/corona-exit-debatte-impfteuch-gegen-das-virus-der-barbarei-af2661b58-775b-4ec3-a421-7917c9abe3f2).

In everyday life focus on an individual provides a solid foundation for a liberal, free, humane and democratic society being a highly sensitive indicator of social relationships. It has acted (history proves it) as a reliable antidote to all authoritative and totalitarian doctrines which have relied on ideas of common, collective or people, nationhood, etc, as a central view without rejecting the notion of identity. Such a disgusting approach is wellknown. (Jörg Bong. Corona-Exit-Debatte: Impft Euch gegen das Virus der Barbarei! DER SPIEGEL - Kultur. 03.04.2020. https://www. spiegel.de/kultur/corona-exit-debatte-impfteuch-gegen-das-virus-der-barbarei-af2661b58-775b-4ec3-a421-7917c9abe3f2).

(6) Darüber hinaus traf es auch eins der höchsten Freiheiten unseres Staates - die Glaubensfreiheit. Für einen möglichen Schutz 
des Kollektivs wurden individuelle Interessen zurückgestuft und dem Bürger die Entscheidungsgewalt entzogen - der Staat entscheidet in der aktuellen Krise für und über die Bürger. Das Staatswesen tritt dabei als Vertretung der Öffentlichkeit auf-es diktiert die Meinung und stuft Interessen ein. (Die Coronakrise stellt den Staat auf eine harte Probe. The European, 31.03.2020. https://www.theeuropean.de/ marc-jacob/die-coronakrise-stellt-den-staatauf-eine-harte-probe/).

Moreover, this concerned one of the top priority liberties of our country - religious liberty. To protect the collective, importance of personal interests was reduced and people were deprived of the right to make decisions. In the present-day crisis the government decides for the people and without people. It acts as a representative of a civil society, it imposes its opinion and decides what values are important. (Die Coronakrise stellt den Staat auf eine harte Probe. The European, 31.03.2020. https://www.theeuropean.de/marc-jacob/diecoronakrise-stellt-den-staat-auf-eine-harteprobe/).

\section{Conclusion}

The pandemic has given great impetus to discussion of the society readiness for global control. It encouraged the society to reconsider many crucial principles of social communication, relationships between the government and the citizens. The new reality and the new social practice enabled us to observe language in its social contexts and in its social embeddedness. A linguistic form, once shaped as an index of a unwanted social practice of the past, comes back, because a re-launched, re-instituted practice comes back. By studying the indexical function of language it is possible to see the connection between the linguistic unit (its linguistic form) and the context that this unit acquires its social voice in. This means it becomes easily predictable, recognizable and typical due to the established opinions, presuppositions, communicators' background. Based on observations about the way in which our language is incorporated in social change and reflect it, the linguistics becomes a social science of language-in-society.

\section{References}

Blommaert, J. (2005). Discourse: A Critical Introduction. Cambridge: Cambridge University Press.

Bucholtz, M., Hall K. (2008). All of the above: New coalitions in sociocultural linguistics In Journal of Sociolinguistics. 12/4. P. 401-431.

Bucholtz, M., Hall, K. (eds.) (2011). Sociolinguistics and linguistic anthropology: Strengthening the connections In Special issue of Journal of Sociolinguistics. 12/4. P. 401-545.

Chernyavskaya, V. (2020). Misplaced in contexts, lost in meaning. Context Change as a Cause for Social Misunderstandings: The Case of Kaliningrad and Königsberg In Zeitschrift für Slavistik. 65 (4). 569-584.

Chernyavskaya, V. E. (2019). Corpus-Assisted Discourse Analysis of Russian University 3,0 Identity In Vestnik Tomskogo gosudarstvennogo universiteta. Filologiya - Tomsk State University Journal of Philology 58. 97-114.

Collins, J. (2011). Indexicalities of language contact in an era of globalisation: Engaging with John Gumperz's legacy In Auer P., Roberts C. (eds). In Honour of John Gumperz. Special issue of Text \& Talk. 31/4. S. 407-428.

Coupland, N., Jaworski, A. (2009). The New Sociolinguistics Reader. Basingstoke: Palgrave Macmillan.

Eckert P. Meaning and Linguistic Variation: The Third Wave in Sociolinguistics. Cambridge University Press. 2018.

Gasparyan G. R., Cherniavskaia, V. E. (2014). Text as co-existance in discourse In Voprosy kognitivnoy lingvistiki. Issues of Cognitive Linguistics. 4 (038), 44-51.

Halliday, M. A. K., Hasan, R. (1985). Language, Context and Text: Aspects of Language in socio-semiotic Perspective. Oxford University Press.

Jakobson, R. (1980 [1957]). Metalanguage as a linguistic problem In The Framework of Language. Michigan Studies in the Humanities 81-92. University of Michigan Press. (First publ. 1957). 
Keßler, Ch. (1997): «...und fügt sich gut ins Kollektiv ein. Muster personenbeurteilender Texte in der DDR. In Barz, Irmhild/Fix, Ulla (Hgg.). Deutsch-deutsche Kommunikationserfahrungen im arbeitsweltlichen Alltag. Heidelberg: Universitätsverlag, 303-314.

Keßler, Ch. (2004). Woran denken Sie bei 'Kollektiv'? Kollektivität als gesellschaftlicher Wert in der DDR und seine kommunikativen Zusammenhänge in Texten In Reiher R., Baumann, A. (Herausgeber). Vorwärts und nichts vergessen: Sprache in der DDR - Was war, was ist, was bleibt. Taschenbuch. S. 184-194.

Kulikova, L. (2011). Akademische Kulturen in Russland und Deutschland: Eine vergleichende Diskursanalyse In Interkulturelle Studien zum Osteuropäischen Sprach-Kulturraum. Berlin: News@Media.

Malinowski, B. (1935). Coral Gardens and their Magic. The Language of Magic and Gardening. London. Allen \& Unwin.

Nefedov, S. T., Towards evaluation in scientific reviews (based on German linguistics). In Journal of Siberian Federal University - Humanities and Social Sciences. 2019, 12(10): 1868-1886.

Nefedov, S. T., Variety of evaluation in communicative practices of academic discourse. In Vestnik Sankt-Peterburgskogo Universiteta.Yazyk i Literatura - Vestnik of Saint Petersburg University. Language and Literature, 2021, 4 (18). (In Print)

Nefedov, S. T., Chernyavskaya, V. E. (2020). Context in linguistics: pragmatic and discourse analytical dimension In Vestnik Tomskogo gosudarstvennogo universiteta. Filologiya - Tomsk State University Journal of Philology 63. 83-97.

Reiher, R. (2000). Das «Kollektiv» hat sich ins «Team» verabschiedet. Regionale Differenzierungen im ostdeutschen Sprachgebrauch. In: Reiher, R./Baumann, A. (Hrsg.) Mit gespaltener Zunge? Die deutsche Sprache nach dem Fall der Mauer. Berlin: Aufbau Taschenbuch, 30-54.

Silverstein, M. (1979). Language Structure and Linguistic Ideology In Paul R. Clyne, William F. Hanks \& Carol L. Hofbauer (eds.) The Elements: A Parasession on Linguistic Units and Levels. S. 193-247. Chicago: Chicago Linguistic Society.

Silverstein, M. (2003). Indexical Order and the Dialectics of Sociolinguistic Life. In Words and Beyond: Linguistic and Semiotic Studies of Sociocultural Order. 23(3). S. 193-229.

Tcherniavskaia V.E. (2014) Discourse paradigm: phantom objects and syndromes. In Voprosy kognitivnoy lingvistiki. Issues of Cognitive Linguistics. 1 (038). pp. 54-61.

Voloshinov, V. N. (2000 [1926]). Word in life and word in poetry. On the issues of sociological poetics In M. Bakhtin (under the mask). Freudianism. Formal method in literary criticism. Marxism and philosophy of language. Articles. M. Labyrinth. 72-94. 